\title{
Stress and Coping Strategies of University Teachers in Pakistan
}

\author{
Uzma Quraishi* \\ Fakhra Aziz $^{* *}$ \\ Aishah Siddiquah $^{* * *}$
}

\begin{abstract}
The purpose of the present study was to identify the perceived job stress and stress coping strategies used by the teachers in Pakistani universities. The study used a survey research design comprising two segments: a) first section identifies how the presence of negative factors and the absence of positive factors cause stress for university teachers in their careers. b) The second part identifies the coping strategies used by them to explore the ways for effective stress management. The data was collected by the instruments Perceived Job Stressors (Kanner, Kafry, \& Pines, 1978) and The Coping Inventory (Carver, Scheier, \& Weintraub, 1989) to identify the stressors and the preferred coping strategies used by the faculty. The data indicate that university faculty experience stress both due to presence of negative factors and absence of positive factors. The most important stress coping strategy used by them was positive reinterpretation \& growth, followed by turning to religion, planning, suppression of competing activities, active coping, restraining coping, seeking social support for emotional reasons, acceptance, mental disengagement, alcohol-drug disengagement, focusing on \& venting of emotions. Moreover, age of teachers influence the adaptation of above mentioned three coping strategies namely positive reinterpretation \& growth, turning to religion, and mental disengagement.
\end{abstract}

Keywords: stress, positive experiences, negative factors, coping strategies, positive reinterpretation, Pakistani universities.

\footnotetext{
* Professor of Education, Lahore College for Women University.

** Assistant Professor, Lahore College for Women University.

Email: fakhraaziz2@gmail.com

*** Assistant Professor, Lahore College for Women University.
} 


\section{Introduction}

In the demanding era of quality education, teacher especially those who are teaching in universities have to face various challenges. Universities, as institutions, value teachers' performance rather than departments' performance in assuring the quality education. According to Dura (2002) teacher's role is multifaceted than merely conveying knowledge. Different job related activities and tasks can create stress among the teachers. Kyriako (2001) reported heavy workload along with bad behavior as key stressors for teachers. Boyle, Borg, Falzon and Baglioni (1995) identified that disruptive students' behaviour is the main stressor for teachers that threatens their discipline and control. These stressors can badly affect classroom performance and emotional health of the teacher (Greenwood, Olenjnik \& Parkay, 1990; Yoon, 2002). Studies on job stress have highlighted the impact of stress on employee health Jonge, Bosma, Peter \& Siegrist, 2000; Kudielka, Hanebuth, Känel, Gander, Grande, \& Fischer, 2005). Teachers who have poor coping skills have more absenteeism at job and have more chances of leaving their teaching career (Bowers, 2004). Noor and Ismail (2016) reported highly significant impact of university teachers job stress as it affected not only the teachers themselves, but also their students.

Teachers in higher education institutions are reported to be suffered from occupational stress. This challenging situation of higher education institutes has become the global issue, which is distressing all groups of personnel and societies. Therefore, to study stress and identify its sources and coping strategies is necessary for the sake of quality education. Keeping in consideration the significance of the issue the present research was designed to contribute in the existing literature from Pakistan.

\section{Literature Review}

Iqbal and Kokash (2011) reported that the equilibrium of the body is disturbed by the Stress. It can be either momentary or long lasting, minor or strong, mostly it depends on how long its duration is, how powerful and to what extent teachers possess coping competencies. Coping mean to deal with problems or difficulties in a calm and appropriate manner. Different people have different reactions to the same situation. A task or situation becomes stressful when someone considers it as a threat and beyond his or her coping capability. A situation may be less or more stressful for a person depending on his capacity to deal with it. A number 
of researches has been conducted in the area of coping strategies. Montgomery and Rupp (2005) identified that the main cause of stress is low coping strategies. Lazarus and Folkman (1984) discussed that frequent physical and mental adaptations are required to cope effectively with demanding situations. Stress may be reduced through diverting attention through physical activity or humour, or by developing new skills (Dunham \& Varma, 1998).

Teachers should try to separate their lives at home and workplace and should actively manage the stressful problems (Arikewuyo, 2004). Chan (1998) found that managing the problem is the best way to cope with stress. Training in stress management skills and interpersonal problem solving skills helps in coping with stress. Admiraal, Korthagen, and Wubbels (2000) indicated that modifying thought processes, learning problem-focused strategies and emotion focused strategies are good to deal with stress.

Carver, Scheier, and Weintraub (1989) developed a multidimensional coping inventory to assess the different ways in which people respond to stress. Total thirteen scales of inventory measure multiple aspects of coping strategies as first five were for measuring problem-focused coping; next five scales were for measuring emotional-focused coping; and last three scales were for measuring less useful coping responses. Research on academics ignore their personal emotional experiences. Job stress may result from the presence of negative experiences as well as the absence of positive conditions at workplace. Both the presence of negative aspects and absence of positive factors may lead towards the tediousness, attitudinal and emotional exhaustion (Kanner, et al., 1978).

Hepburn and Brown(2001) opined that organizational factor like expectation from teachers may cause stress among them. Common positive strategies used by teachers to reduce stress include exercise, social resources, avoidance, reading, hobbies, movement, and meditation (Gulwadi, 2006). Yussuf and Popoola (2016) concluded the results of their descriptive cross sectional survey study in Nigeria and reported high prevalence of stress and reported job dissatisfaction and poor mental health have as big determinants of stress. Gunzerath, Connelly, Albert and Knebel (2001) reported coping strategy naming positive reinterpretation as the "optimal subjective outlook", that "acknowledges the realities of the illness, while focusing on the positive aspects to one's situation" (p339). 
In the above context, the present descriptive study was planned to identify the perceived job stress and stress coping strategies used by the teachers in Pakistani universities. The research questions were:

1. What type of stress orsuniversity teachers experience in Pakistan?

2. What are the preferred stress coping strategies of university teachers?

3. How academics of various age group are different in using different stress coping strategies?

\section{Method}

\section{Participants}

Participants of the study were 119 university teachers from public and private universities of Pakistan. About $34 \%$ participants were males and $66 \%$ were females. On the basis of age, participants were classified as: below 25 years (24\%), 25-30 (32\%), and 31-35 (44\%). About $45 \%$ of the participants were having masters' degree, $30 \%$ having MPhil, 18 $\%$ having $\mathrm{PhD}$ and $7 \%$ were holding other degrees. About $20.2 \%$ of the participants were research assistants/ associates, $38 \%$ were lecturers, 34 $\%$ were assistant professors, $18 \%$ were associate professors and $5.9 \%$ were professors.

\section{Instruments}

The data were collected byusing two instruments. The first one was Perceived Job Stressors (Kanner, et al., 1978) and the second one was the coping inventory (Carver et al., 1989) to identify the stress and stress coping strategies used by the teachers.

Perceived Job Stressors comprised 17 positive factors and 14 stressors or negative factors that university faculty may experience at workplace. One negative factor 'Harassment by colleagues' was added in the scale by the researchers. Hence, first instrument comprised a total of 32 factors, out of which 17 aspects were positive and 15 were negative. The second scale comprised 50 coping strategies categorized under 14 factors. Participants were required to respond on a 7-point Likert scale for both of the scales. Demographic information of the faculty was also collected. 


\section{Data Analysis}

Simple descriptive statistics were used to identify the stressors experienced and stress coping strategies used by the academics. ANOVA and post hoc test was applied to identify the difference in coping strategies of academics of various age groups.

Results from the analysis are presented under the following headings:

\section{Section 1 Identification of Stressors Experienced by University Teachers}

Table 1

Positive Factors Experienced by Teachers

\begin{tabular}{lllll}
\hline Sr. No. & Factors & N & M & SD \\
\hline 1 & Complexity & 118 & 4.14 & 1.76 \\
2 & Variety & 118 & 4.03 & 2.07 \\
3 & Autonomy & 116 & 3.48 & 1.81 \\
4 & Significance & 115 & 3.36 & 1.52 \\
5 & Appreciations & 116 & 3.26 & 1.83 \\
6 & opportunity to take time off & 115 & 3.15 & 1.55 \\
7 & Tangible rewards & 115 & 3.12 & 1.69 \\
8 & Sharing & 113 & 3.08 & 1.54 \\
9 & Comfortable environment & 113 & 3.08 & 1.68 \\
10 & Unconditional support & 114 & 3.04 & 1.6 \\
11 & personal relations & 116 & 3.03 & 1.6 \\
12 & Emotional reciprocity & 111 & 2.98 & 1.52 \\
13 & Feedback & 116 & 2.95 & 1.67 \\
14 & Success & 117 & 2.93 & 1.53 \\
15 & Policy influence & 114 & 2.86 & 1.49 \\
16 & Self-actualization & 116 & 2.85 & 1.56 \\
17 & Self-expression & 116 & 2.72 & 1.55 \\
\hline
\end{tabular}

Table 1 shows that except for variety and complexity, which are moderately available to the participants, all positive factors are somewhat absent from their workplace. Hence, this absence of positive factors cause stress to the teachers. 
Table 2

Negative Factors Experienced by Teachers

\begin{tabular}{lllll}
\hline Sr. No. & Factors & N & M & SD \\
\hline 1 & Overload & 116 & 4.91 & 1.78 \\
2 & Demands for proving oneself & 117 & 4.90 & 1.76 \\
3 & Demands for innovation & 116 & 4.84 & 1.68 \\
4 & Under load & 115 & 4.76 & 1.78 \\
5 & Negative consequences & 116 & 4.65 & 1.68 \\
6 & Experience of guilt & 116 & 4.53 & 1.68 \\
7 & Administrative hassles & 115 & 4.49 & 1.68 \\
8 & Bureaucratic interference & 111 & 4.40 & 1.57 \\
9 & Emotional overextension & 111 & 4.38 & 1.65 \\
10 & Environmental pressures & 116 & 4.33 & 1.72 \\
11 & Over extension of commitment and deadlines & 117 & 4.24 & 1.72 \\
12 & Conflicting demands from other people & 114 & 4.19 & 1.92 \\
13 & Physical danger & 116 & 4.09 & 1.84 \\
14 & Harassment by colleagues & 116 & 4.04 & 1.87 \\
15 & Decision load & 115 & 4.03 & 2.07 \\
\hline
\end{tabular}

Table 2 shows that the most important stressor the participants experienced was overload followed by demands for proving oneself, demands for innovation, under load, negative consequences, experience of guilt. Participants experienced these stressors somewhat frequently. Other negative factors like administrative hassles, bureaucratic interference, emotional overextension, environmental pressures, over extension of commitment and deadlines, conflicting demands from other people, physical danger, harassment by colleagues, and decision load are moderately experienced by the participants. Hence, this presence of negative factors cause stress to the academics. 


\section{Section 2 Stress Coping Strategies used by University Teachers}

Table 3

Stress Coping Strategies used by the Faculty

\begin{tabular}{|c|c|c|c|c|}
\hline $\begin{array}{l}\text { Factor/ } \\
\text { Statement }\end{array}$ & Description & $\mathrm{N}$ & $\mathrm{M}$ & SD \\
\hline Factor 1 & $\begin{array}{l}\text { Positive reinterpretation \& growth (Factor mean }= \\
\text { 5.26) }\end{array}$ & 119 & 21.07 & 5.90 \\
\hline 1 & $\begin{array}{l}\text { Trying to see it in different light, to make it seem } \\
\text { more positive }\end{array}$ & 117 & 5.40 & 1.52 \\
\hline 2 & Looking for something good in what is happening & 116 & 5.40 & 1.47 \\
\hline 3 & $\begin{array}{l}\text { Trying to grow as a person as a result of the } \\
\text { experience }\end{array}$ & 117 & 5.38 & 1.51 \\
\hline 4 & Learning something from the experience & 116 & 5.33 & 1.51 \\
\hline Factor 2 & Turning to religion $($ Factor mean $=\mathbf{5 . 1 7})$ & 119 & 20.69 & 6.37 \\
\hline 1 & Putting trust in God & 109 & 5.48 & 1.66 \\
\hline 2 & Seeking God's help & 118 & 5.38 & 1.51 \\
\hline 3 & Praying more than usual & 114 & 5.32 & 1.48 \\
\hline 4 & Trying to find comfort in religion & 118 & 5.29 & 1.64 \\
\hline Factor 3 & Planning $($ Factor mean $=\mathbf{5 . 1 1})$ & 119 & 15.33 & 4.40 \\
\hline 1 & Making a plan of action & 115 & 5.37 & 1.36 \\
\hline 2 & Thinking hard about how to handle the problem best & 116 & 5.26 & 1.52 \\
\hline 3 & Trying to come up with plan about what to do & 115 & 5.19 & 1.37 \\
\hline Factor 4 & $\begin{array}{l}\text { Suppression of competing activities (Factor mean }= \\
\text { 4.97) }\end{array}$ & 119 & 19.87 & 6.28 \\
\hline 1 & $\begin{array}{l}\text { Keeping oneself away from getting distracted by } \\
\text { other thoughts or activities }\end{array}$ & 115 & 5.26 & 1.47 \\
\hline 2 & $\begin{array}{l}\text { Trying hard to prevent other things from interfering } \\
\text { with ones efforts at dealing with this }\end{array}$ & 115 & 5.23 & 1.56 \\
\hline 3 & $\begin{array}{l}\text { Focusing on dealing with this problem and let other } \\
\text { things slide a little if necessary }\end{array}$ & 113 & 5.10 & 1.62 \\
\hline 4 & $\begin{array}{l}\text { Putting aside other activities in order to concentrate } \\
\text { on this }\end{array}$ & 114 & 5.10 & 1.46 \\
\hline Factor 5 & Active Coping $($ Factor mean $=\mathbf{4 . 8 9})$ & 119 & 19.55 & 5.77 \\
\hline 1 & Taking direct action to get around the problem & 116 & 5.11 & 1.59 \\
\hline 2 & Doing what has to be done, one step at a time & 114 & 5.06 & 1.38 \\
\hline 3 & Concentrating efforts on doing something about it & 116 & 5.02 & 1.49 \\
\hline 4 & $\begin{array}{l}\text { Taking additional action to try to get rid of the } \\
\text { problem }\end{array}$ & 117 & 4.91 & 1.68 \\
\hline Factor 6 & Restraining coping $($ Factor mean $=\mathbf{4 . 8 4})$ & 119 & 19.34 & 6.23 \\
\hline 1 & Restraining oneself from doing anything too quickly & 116 & 4.31 & 2.14 \\
\hline 2 & $\begin{array}{l}\text { Making sure not to make matters worse by acting too } \\
\text { soon }\end{array}$ & 114 & 5.27 & 1.48 \\
\hline 3 & $\begin{array}{l}\text { Holding off doing anything about it until the situation } \\
\text { permits }\end{array}$ & 115 & 5.25 & 1.58 \\
\hline 4 & $\begin{array}{l}\text { Forcing oneself to wait for the right time to do } \\
\text { something }\end{array}$ & 114 & 5.24 & 1.54 \\
\hline Factor 7 & Seeking social support for emotional reasons (Factor & 119 & 19.34 & 5.83 \\
\hline
\end{tabular}




\begin{tabular}{|c|c|c|c|c|}
\hline & mean $=4.83)$ & & & \\
\hline 1 & Getting sympathy and understanding from someone & 117 & 5.06 & 1.66 \\
\hline 2 & Discussing feelings with someone & 116 & 5.01 & 1.57 \\
\hline 3 & Talking to someone about feeling & 114 & 4.96 & 1.48 \\
\hline 4 & $\begin{array}{l}\text { Trying to get emotional support from friends and } \\
\text { relatives }\end{array}$ & 116 & 4.86 & 1.56 \\
\hline Factor 8 & Acceptance $($ Factor mean $=\mathbf{4 . 6 9})$ & 119 & 18.76 & 5.65 \\
\hline 1 & $\begin{array}{l}\text { Accepting that his has happened and that it can be } \\
\text { changed }\end{array}$ & 113 & 5.38 & 1.34 \\
\hline 2 & Accepting the reality that it happened & 75 & 5.35 & 1.37 \\
\hline 3 & Learning to live with it & 117 & 5.32 & 1.46 \\
\hline 4 & Getting used to the idea that it happened & 115 & 5.23 & 1.35 \\
\hline Factor 9 & Mental disengagement $($ Factor mean $=\mathbf{4 . 6 0})$ & 119 & 18.41 & 6.00 \\
\hline 1 & Day dreaming about things other than this & 117 & 4.75 & 1.80 \\
\hline 2 & Going to movies or watching TV to think about it less & 118 & 4.72 & 1.69 \\
\hline 3 & Sleeping more than usual & 117 & 4.67 & 1.82 \\
\hline 4 & $\begin{array}{l}\text { Turning to work or other substitute activities to take } \\
\text { mind off things }\end{array}$ & 115 & 4.63 & 1.55 \\
\hline Factor 10 & Alcohol-drug disengagement $($ Factor mean $=\mathbf{4 . 6 0})$ & 117 & 4.60 & 2.22 \\
\hline 1 & $\begin{array}{l}\text { Taking drugs to feel better or forget the stressful } \\
\text { things }\end{array}$ & 117 & 4.60 & 2.22 \\
\hline Factor 11 & $\begin{array}{l}\text { Focusing on \& venting of emotions (Factor mean }= \\
\text { 4.58) }\end{array}$ & 119 & 13.74 & 4.64 \\
\hline 1 & Let ones feelings out & 115 & 4.77 & 1.59 \\
\hline 2 & Getting upset and let emotions out & 115 & 4.71 & 1.68 \\
\hline 3 & $\begin{array}{l}\text { Feeling a lot of emotional distress and expressing a } \\
\text { lot }\end{array}$ & 118 & 4.62 & 1.57 \\
\hline Factor 12 & $\begin{array}{l}\text { Seeking social support for instrumental reasons } \\
(\text { Factor mean }=\mathbf{4 . 2 9} \text { ) }\end{array}$ & 119 & 17.18 & 7.30 \\
\hline 1 & $\begin{array}{l}\text { Trying to get advice from someone about the } \\
\text { situation }\end{array}$ & 117 & 4.79 & 1.66 \\
\hline 2 & $\begin{array}{l}\text { Talking to someone to find out more about the } \\
\text { situation }\end{array}$ & 75 & 5.25 & 1.64 \\
\hline 3 & $\begin{array}{l}\text { Talking to someone who could do something concrete } \\
\text { about the problem }\end{array}$ & 113 & 4.95 & 1.50 \\
\hline 4 & $\begin{array}{l}\text { Asking people who have had similar experiences } \\
\text { what they did }\end{array}$ & 116 & 4.58 & 1.88 \\
\hline Factor 13 & Behavioral disengagement $($ Factor mean $=\mathbf{4 . 0 3})$ & 119 & 16.11 & 6.54 \\
\hline 1 & Giving up the attempt to get what one wants & 115 & 4.59 & 1.76 \\
\hline 2 & Reducing the amount of effort to solve the problem & 117 & 4.25 & 1.82 \\
\hline 3 & Admitting that one can 't deal with it and quit trying & 118 & 3.96 & 1.90 \\
\hline 4 & Just giving up trying to reach the goal & 116 & 3.66 & 1.99 \\
\hline Factor 14 & Denial $($ Factor mean $=\mathbf{3 . 8 8})$ & 119 & 11.63 & 4.62 \\
\hline 1 & Refusing to believe that it has happened & 117 & 4.62 & 1.60 \\
\hline 2 & Saying to oneself this is not real & 118 & 4.50 & 1.63 \\
\hline 3 & Pretending that it has not really happened & 75 & 4.17 & 1.90 \\
\hline
\end{tabular}

Table 3 shows that the most important stress coping strategy used by the university faculty was positive reinterpretation $\&$ growth, followed 
by turning to religion, planning, suppression of competing activities, active coping, restraining coping, seeking social support for emotional reasons, acceptance, mental disengagement, alcohol-drug disengagement, and focusing on \& venting of emotions. All of these coping strategies were used somewhat frequently by the university faculty. The stress coping strategies moderately used by academics are seeking social support for instrumental reasons, followed by behavioral disengagement, and denial.

Table 4

Differences in Coping Strategies used by Faculty Belonging to Different Age Groups

\begin{tabular}{|c|c|c|c|c|c|c|c|}
\hline $\begin{array}{l}\text { Coping } \\
\text { strategy }\end{array}$ & & $\begin{array}{l}\text { Sum of } \\
\text { Squares }\end{array}$ & $d f$ & $\begin{array}{l}\text { Mean } \\
\text { Square }\end{array}$ & $\mathrm{F}$ & $\mathrm{p}$ & Post hoc \\
\hline \multirow{3}{*}{$\begin{array}{l}\text { Positive } \\
\text { reinterpretation } \\
\text { \& growth }\end{array}$} & $\begin{array}{l}\text { Between } \\
\text { n Groups }\end{array}$ & 448.294 & 6 & 74.716 & \multirow[t]{3}{*}{2.584} & \multirow[t]{3}{*}{.022} & \multirow{3}{*}{$\begin{array}{l}\text { below } 25 \text { years } \\
<25-30,35-40 \text {, } \\
41-50,51-60 \\
31-35<41-50\end{array}$} \\
\hline & $\begin{array}{l}\text { Within } \\
\text { Groups }\end{array}$ & 3209.579 & 111 & 28.915 & & & \\
\hline & Total & 3657.873 & 117 & & & & \\
\hline \multirow[t]{3}{*}{$\begin{array}{l}\text { Turning } \\
\text { religion }\end{array}$} & $\begin{array}{l}\text { o Between } \\
\text { Groups }\end{array}$ & 659.809 & 6 & 109.968 & \multirow[t]{3}{*}{3.308} & \multirow[t]{3}{*}{.005} & \multirow{3}{*}{$\begin{array}{l}\text { below } 25 \text { years } \\
<25-30,31-35, \\
35-40, \\
51-60\end{array}$} \\
\hline & $\begin{array}{l}\text { Within } \\
\text { Groups }\end{array}$ & 3690.405 & 111 & 33.247 & & & \\
\hline & Total & 4350.214 & 117 & & & & \\
\hline \multirow{3}{*}{$\begin{array}{l}\text { Mental } \\
\text { disengagement }\end{array}$} & $\begin{array}{l}\text { Between } \\
\text { t Groups }\end{array}$ & 442.787 & 6 & 73.798 & \multirow[t]{3}{*}{2.363} & \multirow[t]{3}{*}{.035} & \multirow{3}{*}{$\begin{array}{l}31-35>25-30 \\
35-40>\text { below } \\
25 \text { years, } 25-30\end{array}$} \\
\hline & $\begin{array}{l}\text { Within } \\
\text { Groups }\end{array}$ & 3466.170 & 111 & 31.227 & & & \\
\hline & Total & 3908.958 & 117 & & & & \\
\hline
\end{tabular}

Table 5 shows that the coping strategies i.e. positive reinterpretation and growth was being used significantly less by the teachers with age below 25 than it was being used by the teachers with age group 25-30 and more than 35 years. Similarly, teachers with age 31-35 were using this coping strategy significantly less than the teachers with age 41-50. Stress coping strategy turning to religion was being used significantly less in faculty members with age below 25 years than it was being used by the faculty members of all other age groups. Moreover, it was found that 
mental disengagement was found more in middle age group. Faculty members in the 31-35 age group use mental disengagement significantly more than the teachers of age group 25-30 and faculty members in the age group 35-40 use this stress coping strategy significantly more than the teachers with age below 30 years.

\section{Discussion}

It has been found that in reputed public and private universities, teachers experience a number of stressors. This stress is both due to presence of negative factors and absence of positive factors at workplace. The most important negative factor was found to be overload followed by demands for proving oneself, demands for innovation, under load, negative consequences, experience of guilt, administrative hassles, bureaucratic interference, emotional overextension, environmental pressures, over extension of commitment and deadlines, conflicting demands from other people, physical danger, harassment by colleagues, and decision load are moderately experienced by the participants. Hence, this presence of negative factors cause stress to the academics. Only two positive factors, variety and complexity are moderately available to the teachers. Rest of the positive factors were somewhat absent, which also cause stress to the them. To cope with stress, positive reinterpretation \& growth was most frequently used by the teachers followed by turning to religion, planning, suppression of competing activities, active coping, restraining coping, seeking social support for emotional reasons, acceptance, mental disengagement, alcohol-drug disengagement, focusing on \& venting of emotions, seeking social support for instrumental reasons, behavioral disengagement, and denial. Young teachers used two stress coping strategies positive reinterpretation and growth and turning to religion significantly less than the elder group. Teachers of middle age group used stress coping strategy mental disengagement significantly more than of other age groups.

These results are in line with the researches already conducted in the area. Abbas (2012) narrated that teachers who had job experience above 5 years found to be more stressed as compare to teachers who had job experience less than 5 years. Ndom, Makanjuola (2004) Shimizu, Hiro, Mishan , Nagata (2002) reported higher level of stress among older doctors. Earlier Griffit(1999) concluded that younger and less experienced teachers affected more by stress than older and more experienced teachers. He further reported junior teachers to be more stressed than senior teachers. Contrary to them, Al- Mutawa (2014) 
found that stress level does not influenced by sex, age, academic qualification, job experience, nationality, income level and subject area.

While regarding coping strategies, Parven (2013) provided a list of most used coping strategies among teachers including prayers, time management, relaxation, writing \& reading, food, exercises, spent time with family, socialization, entertainment, therapist, yoga and meditation, stress control workshops and medications. Many coping strategies used by Pakistani academicians reported in the present research are included in this list. Further Grace (2014) also presented a list of significant coping strategies and narrated that senior faculty reduced their stress by challenging, isolation, self-controlling, seeking social support, accepting responsibility, not avoiding, problem-solving and positive reflection.

\section{Conclusion}

The present study provides an insight about the stressor and the stress management strategies used by the university teachers in Pakistan. The study highlights the extent to which they experience various positive and negative factors in universities. Research also revealed the differences in coping strategies of teachers based on their age group. Researchers and policymakers must pay attention to the careers of teachers to promote the quality of higher education. There must be workshops and training sessions for them on the stress management. It is also recommended that a further study be conducted on a larger scale to explore different work place stressors and to compare coping strategies against demographic variables. 


\section{References}

Abbas, S. G. Roger A., \& Asadullah, M. A. (2012). Impact of organizational role stressors on faculty stress and burnout. 4ème collogue international (ISEOR - AOM), 1-18.

Yussuf \& Popoola. (2016). Prevalence and correlates of job stress among junior Doctors in the University college hospital, Ibadan, Ann Ib Postgrad Med.14(2) 92-98.

Admiraal, W. F., Korthagen, F. A. J., \& Wubbels, T. (2000). Effects of student teachers' coping behaviour. British Journal of Educational Psychology, 70, 33-52.

Arikewuyo, M. O., (2004). Stress management strategies of secondary school teachers in Nigeria. Educational research, 46(2), 195-207.

Bowers, T. (2004). Stress teaching and teacher health. Education, 32(3), 3-13.

Boyle, G. J., Borg, M. G., Falzon, J. M., \&Baglioni, A. J. (1995). A structural model of the dimensions of teacher stress. British Journal of Educational Psychology, 65 (1), 49-67.

Carver, C. S., Scheier, M. F., \& Weintraub, J. K. (1989). Assessing coping strategies: A theoretically based approach. Journal of Personality and Social Psychology, 56, 267-283.

Chan, D. W. (1998). Stress, coping strategies, and psychological distress among secondary school teachers in Hong Kong. American Educational Research Journal, 35(1), 145-163.

De Jonge, J., Bosma, H., Peter, R., \&Siegrist, J. (2000). Job strain, effortreward imbalance and employee well-being: a large-scale crosssectional study. Social Science \& Medicine, 50, 1317-1327.

Dunham, J., \& Varma, V. (1998). Stress in teachers: Past, present and future. London: Whurr Publishers Ltd.

Durka, G. (2002). The teachers calling: A spirituality for those who teach. New Jerse: Paulist Press.

Greenwood, G. E., Olejnik, S. F., \& Parkay, F. W. (1990). Relationships between four teacher efficacy belief patterns and selected teacher characteristics. Journal of Research \& Development in Education, 23(2), 102-106. 
Griffith, J., Steptoe, A., \& Cropley, M. (1999). An investigation of coping strategies associated with job stress in teachers. British Journal of Psychology, 69, 517-13.

Gunzerath, L., Connelly, B., Albert, P., \& Knebel, A. (2001). Relationship of personality traits and coping strategies to quality of life in patients with alpha-1 antitrypsin deficiency. Psychological Health \& Medicine, 6(3), 335-341.

Hepburn, A., \& Brown, S. (2001). Teacher stress and management of accountability. Human Relations, 54(6), 691-715.

Iqbal, A.,\& Kokash, H. (2011). Faculty perception of stress and coping strategies in a Saudi Private University: An exploratory study. Journal of International Education Studies, 4 (3), 137-49.

Kanner, A., Kafry, D., \& Pines, A. (1978). Conspicuous in its absence: The lack of positive conditions as a source of stress. Journal of Human Stress, 4, 33-39.

Kudielka, B. M., Hanebuth, D., Känel, R., Gander, M., Grande, G., \& Fischer, J. E. (2005). Health-Related quality of life measured by the SF12 in working populations: associations with psychosocial work characteristics. Journal of Occupational Health Psychology, 10 (4), $429-440$.

Kyriacou, C. (2001). Teacher stress: Directions for future research. Educational Review, 53 (1), 27-35.

Lazarus, R. S., \& Folkman, S. (1984). Stress, appraisal, and coping. New York: Springer.

Montgomery, C., \& Rupp, A. A. (2005). A Meta-analysis for exploring the diverse causes and effects of stress in teachers. Canadian Journal of Education, 28(3), 458-486.

Ndom, R.J.,\& Makanjuola, A.B. (2004). Perceived stress factors among resident doctors in a Nigerian teaching hospital. West African journal of medicine. 232-235.

Shimizu, T., Hiro, M., Mishan, N, Nagata, S. Job Stress among Japanese Full-Time Occupational Physicians. J Occup Health, 44(5), 348354. 
Noor, A., \& Ismail, N. H.(2016) Occupational stress and its associated factors among academician in a research university, Malaysia. Malaysian Journal of Public Health Medicine, 16 (1), 81-91

Parveen, M. (2013). Faculty stress in a Saudi government University. International Journal of Humanities and Social Science, 3(18), $180-$ 92.

Yoon, S. (2002). Teacher characteristics as predictors of teacher-student relationships: stress, negative affect, and self-efficacy. Social Behavior and Personality: an international journal, 30 (5), 485-493.

\section{Citation of this Article:}

Quraishi, U., Aziz, F., \& Siddiquah, A. (2018). Stress and coping strategies of university teachers in Pakistan. Pakistan Journal of Education, 35(2), 193-206.

$\begin{array}{ll}\text { Received on: August } & 29,2017 \\ \text { Revised on: June } & 19,2018 \\ \text { Accepted on: July } & 04,2018\end{array}$

